\title{
ANALISIS VARIABILITAS CURAH HUJAN KOTA MARTAPURA KALIMANTAN SELATAN AKIBAT PERUBAHAN IKLIM
}

\author{
M. Djazim Syaifullah ${ }^{1}$, Fikri Nur Muhammad ${ }^{2}$, Ibnu Athoillah ${ }^{3}$, Samba Wirahma ${ }^{4}$
}

\begin{abstract}
Intisari
Negara Indonesia merupakan Negara Kepulauan yang terletak di Khatulistiwa sehingga rentan terhadap perubahan iklim.Curah hujan yang terjadi di suatu tempat dipengaruhi oleh faktor alam dan topografi daerah tersebut. Dengan melihat histori kejadian hujan selama 70 tahun (1915 - 2000) akan mengetahui pola hujan distribusi curah hujan suatu wilayah. Untuk memperoleh hasil tersebut digunakan analisa regresi. Dalam analisa tersebut didapatkan dari tahun 1915 sampai dengan tahun 2000 untuk stasiun di Kota Martapura menunjukan pola kecerendungan kenaikan $4,5898 \mathrm{~mm} / \mathrm{tahun}$ dengan persamaan regresi $Y=4.5898 X-6600.4$ with $R^{2}=0.0513$.
\end{abstract}

\begin{abstract}
State of Indonesia is a country located on the equator that are vulnerable to climate change. Rainfall (precipitation) that occurs in a place influenced by nature and topography of the area. By knowing historical rainfall events during 70 years (1915-2000) will determine the distribution pattern of rainfall in the area. To obtain the result about distribution pattern used regression analysis. In the regression analysis obtained that from 1915 until 2000 year for station in Martapura shows the rise pattern 4,5898 $\mathrm{mm} /$ years with a regression equation $Y=4.5898 X-6600.4$ with $R^{2}=0.0513$.
\end{abstract}

Kata kunci :TRMM, Radiosonde, banjir.

\section{PENDAHULUAN}

Indonesia merupakan negara maritime continental yang kaya akan uap air dan terdiri dari berbagai kepulauan. Hal ini disebakan karena Indonesia berada di antaradua samudera, Samudera Pasifik dan Samudera HindiaSelain itu letak Indonesia yang berada di garis Khatulistiwamengakibatkan rentan terhadap perubahan iklim.

Dampak serius dengan adanya perubahan iklim yang dihadapi oleh Indonesia antara lain perubahan pola curah hujan, banjir, kekeringan maupun kenaikan muka air laut dan perubahan suhu. Untuk menghindari dampak perubahan iklim yang lebih parah, para IImuwantelah memperingatkan bahwa kenaikan suhu global harus dibawah $2^{\circ} \mathrm{C}$ (dibanding revolusi industri). Pembakaran bahan bakar fosil, dalam hal ini minyak bumi, batubara dan gas bukan satusatunya yang mempengaruhi pemanasan global, akan tetapi kerusakan hutan juga termasuk salah satu yang bertanggung jawab atas emisi efek rumah kaca.

Salah satu pulau yang terbesar di Indonesia adalah Pulau Kalimantan, dimana pulau tersebut memiliki aneka tambang yang tersebar di berbagai tempat.Selain itu Pulau Kalimantan juga termasuk Pulau terbesar ketiga di dunia dan terkenalsebagai hutan yang kaya akan hujan
(Kumagai et al 2013).

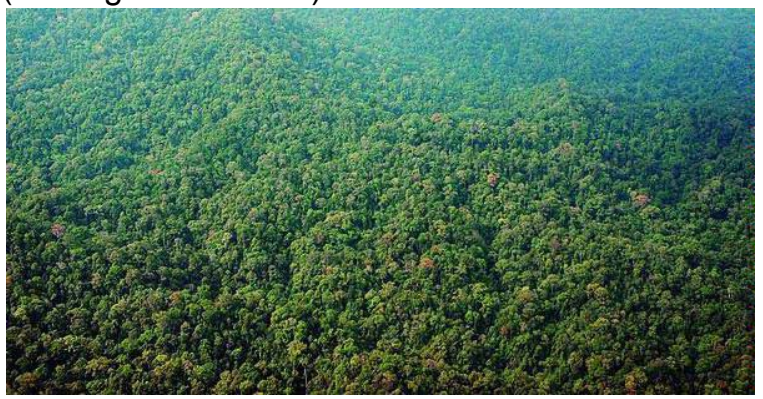

Gambar 1. Hutan Tropis Kalimantan

Dalam penelitian ini akan membahas mengenai variabilitas curah hujan yang terjadi di bagian Kalimantan Selatan, tepatnya di Kota Martapura, hal ini menarik dilakukan untuk melihat apakah curah hujan di Kota Martapura mengalami kenaikan ataupun penurunan. Karena dalam penelitian yang pernah ditulis oleh Kumagai dkk tahun 2013 dalam paper yang berjudul "Deforestation-induced Reduction in Rainfall" menjelaskan bahwa Borneo atau yang sering disebut oleh orang Indonesia dengan Kalimantan mengalami penurunan curah hujan sejak tahun 1950-2007. Hal ini dikarenakan adanya deforestasi hutan. Menurut data yang dikeluarkan oleh Kementerian Kehutanan, untuk Pulau Kalimantan pada tahun 2000 sampai dengan 2005 mencapai 
1,23 juta hektare. Deforestasi di Indonesia yang terjadi di Indonesia kebanyakan disebabkan oleh banyaknya aktivitas perusahaan-perusahaan yang memanfaatkan hutan baik untuk membuka tambang maupun perkebunan. Berikut merupakan grafik curah hujan yang terjadi di Kalimantan selama 1950-2007

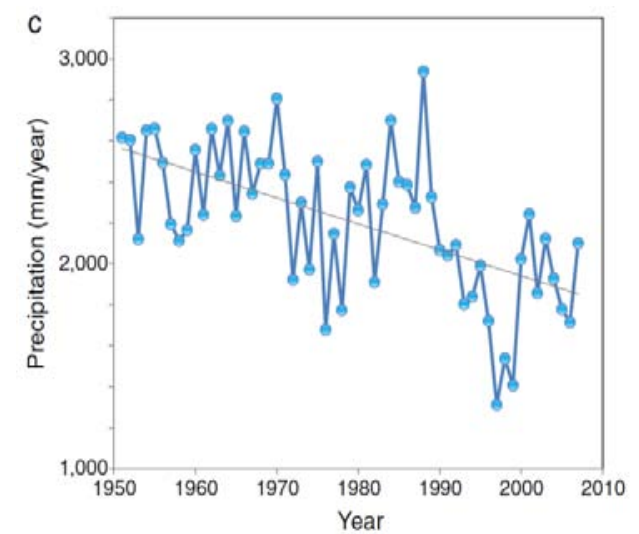

Gambar 2. Distribusi Curah Hujan di Kalimantan (Kumagai et al 2013)

Dalam grafik tersebut, curah hujan mengalami penurunan sebesar $-12,7 \mathrm{~mm} /$ tahun selama periode 1950-2007. Dengan melihat pola distribusi curah hujan suatu daerah khususnya Kota Martapura maka nantinya akan dapat digunakan sebagai salah satu sumber untuk melihat atau mempertimbangkan dalam merencanakan tata Kota (pengairan, irigasi, pembangkitan listrik) yang baik.

Adapun metode pendekatan yang digunakan dalam penelitian ini yaitu menggunakan data curah hujan dan hari hujan bulanan daerah suatu titik tertentu (Point Rainfall) di daerah Kota Martapura yang didapat dari data BMKG.

\section{TINJAUAN PUSTAKA}

\subsection{Intensitas Curah Hujan}

Intensitas hujan merupakan tinggi hujan persatuan waktu, dapat berupa $\mathrm{mm} /$ menit, $\mathrm{mm}$ ljam atau mm/hari. Apabila dikatakan intensitasnya besar berarti hujan yang terjadi sangat lebat dan kemungkinan kondisi ini sangat berbahaya karena akan berdampak dapat menimbulkan banjir, longsor, dll. Jika kita mempunyai data hujan harian dan diinginkan data hujan jangka pendek misalnya 5 menit, 30 menit, 60 menit dan jam-jaman dapat dihitung dengan menggunakan persamaan Mononobe(Soemanto, 1995)

$$
I=\frac{R_{24}}{24}\left(\frac{24}{t}\right)^{\mathrm{m}}
$$

Dimana :

$$
\mathrm{I}=\text { intensitas curah hujan }(\mathrm{mm} / \mathrm{jam})
$$

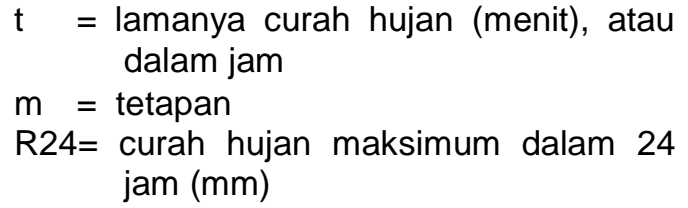

\subsection{Analisi Regresi}

Dalam penelitian ini digunakan analisa regresi.Analisa regresi merupakan analisa stastistika yang memanfaatkan hubungan antara dua atau lebih peubah kuatitatif dimana nangtinya salah satu peubah dapat diramalkan dari peubah lainnya. Secara umum untuk model regresi liner sederhana dapat dituliskan :

$$
Y \_(i)=\beta \_0+\beta \_1 X \_i+\varepsilon \_i \quad i=1,2, \ldots, n
$$

- Yi merupakan nilai peubah tak bebas dalam pengamatan ke-i

- $\quad \beta 0$ dan $\beta 1$ merupakan parameter

- Xi adalah konstanta yang diketahui,yaitu nilai peubah bebas dari pengamatan ke-i

- $\quad$ ci adalah galat yang bersifat acak dengan rataan $\mathrm{E}[\varepsilon \mathrm{i}]=0$

$$
\text { Sehingga : } E\left[Y \_i\right]=\beta \_0+\beta \_1 X \_i
$$

Secara grafik, persamaan diatas dapat digambar sebagai berikut :

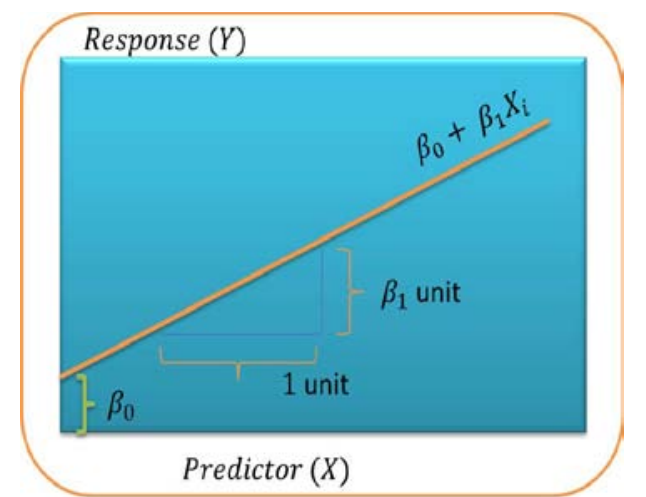

Gambar 3. Model Regresi Linier Sederhana

\subsubsection{Uji Normalitas Data}

Uji normalitas data diperlukan untuk mengetahui apakah data berdistribusi normal.Salah satu metode pengujian normalitas data adalah menggunakan teknik KolmogorovSmirnov.Teknik tersebut menguji perbedaan antara data yang diuji normalitasnya dengan data normal baku. Jika tingkat signifikansinya di bawah 0,05 ( $p$-value < 0,05), berarti terdapat perbedaan yang signifikan antara data yang diuji dengan data normal baku sehingga dapat disimpulkan data tersebut tidak terdistribusi normal. Sebaliknya jika tingkat di atas 0,05( $p$-value $>0,05)$ maka tidak ada perbedaan signifikan sehingga data tersebut dapat disimpulkan terdistribusi normal. 


\section{METODE PENELITIAN}

\section{$3.1 \quad$ Lokasi}

Kota Martapura terletak di $3^{\circ} 24^{\prime} 42.60^{\prime \prime}$ Lintang Selatan (LS) dan 114050"40.73" Bujur Timur (BT).Kota tersebut di bagian timur hingga tenggara di kelilingi oleh bukit-bukit. Pemilihan Kota Martapura menjadi lokasi penelitian dikarenakan kota tersebut merupakan salah satu Kota yang terkenal di Pulau Kalimantan dengan Kota Intan dan terdapat data histori curah hujan yang cukup banyak.

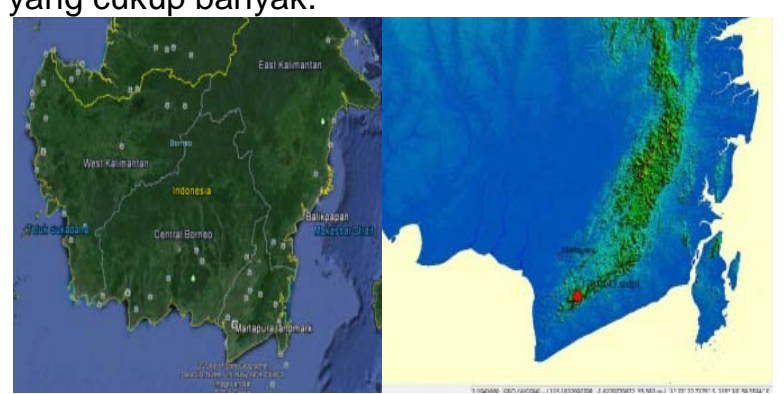

Gambar 4. Letak Geografis Kota Martapura

\subsection{Data}

Dalam menganalisa variabilitas data curah hujan digunakan data dari BMKG (Badan Meteorologi, Klimatologi dan Geofisika) dari tahun 1915 - 2000 dari stasiun hujan Martapura.Stasiun ini dipilih karena mempunyai data pengamatan yang cukup panjang.

\subsection{Tahap Analisis}

Pengelompokan data dalam penelitian ini adalah data dibedakan dalam data musim hujan (Nopember - April) dan data musim kemarau (Mei - Oktober).Data Dikelompokkan menjadi periode 1 (1915-1923), periode 2 (1924-1932), periode 3 (1933-1941), periode 4 (1946-1954), periode 5 (1955-1963), periode 6 (1964-1972), periode 7 (1973-1981), periode 8 (1990-2000). Dengan batasan untuk periode 8 tahun 1993 dan 1994 tidak ada data yang tercatat. Kekosongan data tersebut kemungkinan tidak adanya pengamatan maupun alat yang digunakan sedang rusak.Periode 1 (1915-1923) dijadikan dasar dalam penelitian ini, dengan asumsi pada periode ini kondisi masih normal.
Uji normalitas data. Uji normalitas data dilakukan untuk mengetahui apakah data yang akan digunakan mempunyai sebaran normal atau tidak. Jika data yang digunakan normal maka dianggap data tersebut dapat mewakili populasi sehingga dapat digunakan untuk analisis.

Uji statistik. Uji statistik dilakukan untuk membuktikan terjadi perubahan pola curah hujan sebagai tanda terjadi perubahan iklim dengan test hipotesis dengan membandingkan setiap periode curah hujan dengan kondisi awal (1915-1923).

Analisis Regresi. Analisis regresi linier Berganda dilakukan untuk mengetahui arah hubungan antara variabel dependen dengan variabel independen berhubungan positif atau negatif.

Uji F. Uji F digunakan untuk mengetahui pengaruh variabel bebas secara bersama-sama (simultan) terhadap variabel terikat.Dengan menggunakan tingkat siginifikansi $0.05 \quad(5 \%)$, maka nilai probabilitas < 0.05 dikatakan mempunyai pengaruh yang signifkan sedangkan nilai probabilitas $>0.05$ maka tidak berpengaruh signifikan secara bersama-sama antara variabel bebas terhadap variabel terikat.

Uji t. uji t digunakan untuk menguji secara parsial masing-masing variabel. Jika nilai probabilitas $t<$ 0.05 maka terdapat pengaruh antara variabel bebas dengan variabel terikat secara parisal,sedangakan jika nilai probabilitas $t>0.05$ maka tidak terdapat pengaruh yang siginifikan antara masing-masing variabel bebas dengan variabel terikat.

\section{HASIL}

Berdasarkan distribusi temporal pada gambar 5, menunjukan puncak musim hujan terjadi pada bulan Januari dan Desember untuk periode $1,2,3,6$ maupun 8 , periode 4 puncak musim hujan terjadi pada bulan Maret dan Desember, periode 5 puncak musim hujan terjadi pada bulan Januari dan Februari dan untuk peiode 7 puncak musim hujan terjadi pada bulan Februari dan Desember. Puncak musim kemarau terjadi pada bulan September untuk periode 1 dan 4 bulan Agustus untuk periode 2,3,5,6,7 dan 8 . 


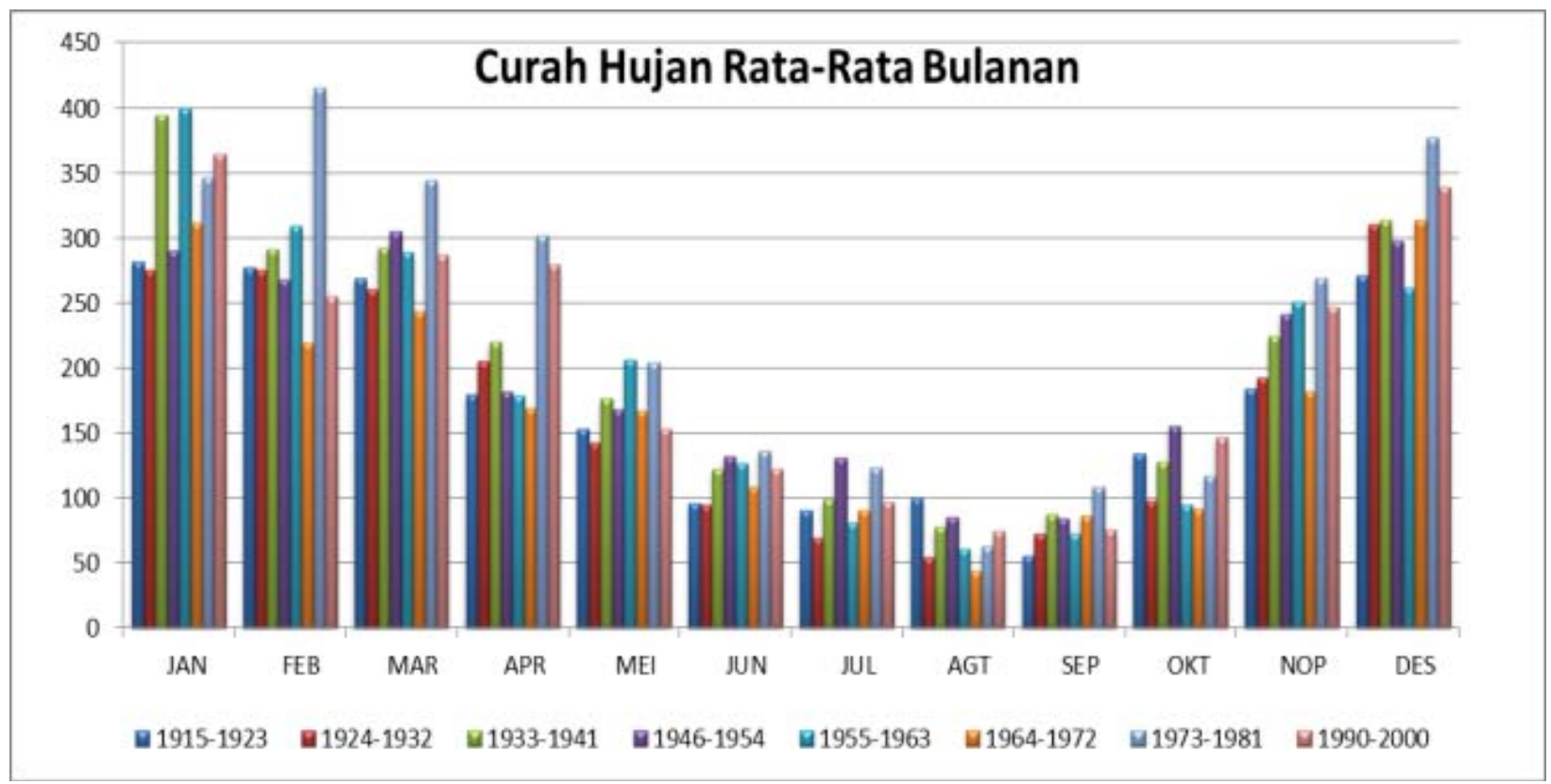

Gambar 5. Curah hujan rata-rata bulanan di Stasiun Cuaca Kota Martapura untuk 8 periode

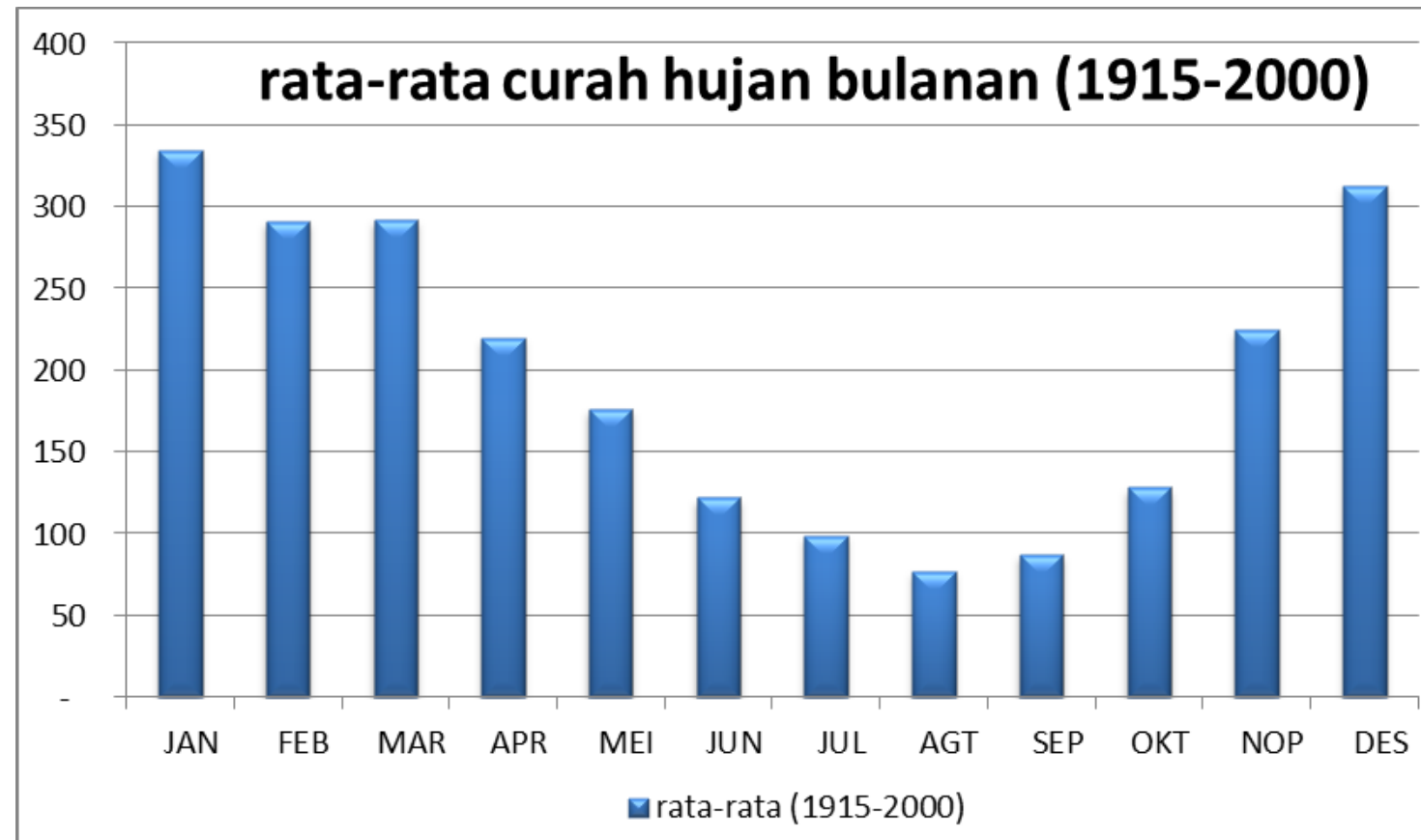

Gambar 6. Curah hujan rata-rata bulanan di Stasiun Cuaca Kota Martapura(tahun 1915-2000)

Secara umum berdasarkan grafik diatas, musim kemarau terjadi antara bulan Juni sampai dengan bulan September.

Hasil serupa dapat ditunjukan oleh data satelit dari TRMM (Tropical Rainfall Measuring Mission) yang menunjukan perbedaan jumlah curah hujan bulanan antara bulan Januari, Juli, Agustus dan September.Dalam tulisan ini, penulis menyajikan data TRMM untuk tahun $2008 \mathrm{ke}$ atas. Hal ini dikarenakan data TRMM mulai ada pada tahun
2008. Gambar berikut menunjukan adanya perbedaan antara bulan Januari, Juli, Agustus dan September tahun 2010 untuk Kota Martapura dan sekitarnya. Bulan Januari menunjukan curah hujan yang cukup signifikan dibandingkan dengan bulan Juli, Agustus dan September. Bulan Januari daerah Kota Martapura mencapai kurang lebih 400-500 mm sedangkan bulan Juli mencapai 100$150 \mathrm{~mm}$ dan bulan Agustus mencapai 150-200 $\mathrm{mm}$. 


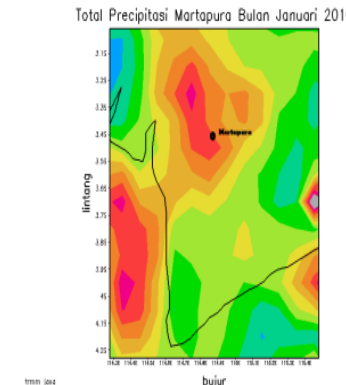

a).

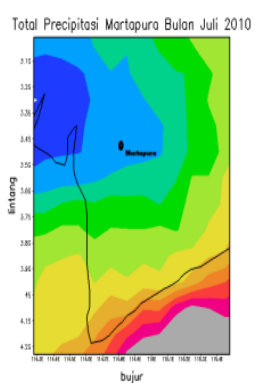

b).

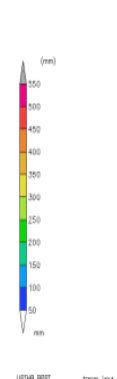

c).

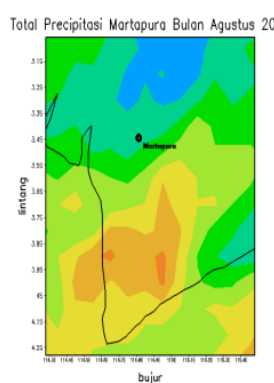

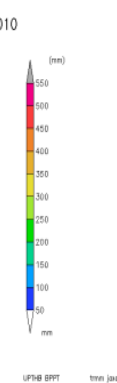

Agustus $(d$

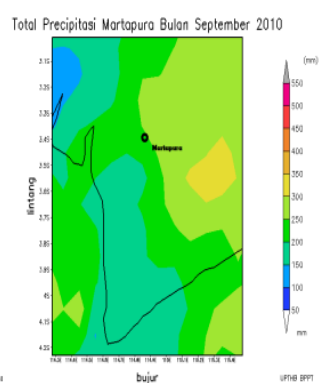

d).

Gambar 7. Citra Satelit TRMM tahun 2010 (a).Januari (b).Juli (c).Agustus (d).September

\subsection{Uji Normalitas Data}

Hasil uji Kolmogorov-Smirnov untuk tes kenormalan data siklus musim hujan diperoleh nilai signifikansi untuk semua periode musim hujan sebesar 0.2 , kecuali untuk periode 7 sebesar 0,07 akan tetapi semua siklus musim hujan mempunyai nilai signifikansi $>0.05$ sehingga residual model regresi yang dilakukan berdistribusi normal.

\begin{tabular}{|c|c|c|c|c|c|c|}
\hline \multicolumn{7}{|c|}{ Te sts of Normality } \\
\hline & \multicolumn{3}{|c|}{ Kolmogorov-Smirnov ${ }^{\mathrm{a}}$} & \multicolumn{3}{|c|}{ Shapiro-Wilk } \\
\hline & Statistic & df & Sig. & Statistic & df & Sig. \\
\hline hujan_1 & .197 & 9 & $.200^{\star}$ & .879 & 9 & .153 \\
\hline hujan_2 & .180 & 9 & $.200^{*}$ & .889 & 9 & 197 \\
\hline hujan 3 & .216 & 9 & $.200^{\star}$ & .880 & 9 & .156 \\
\hline hujan_4 & .212 & 9 & $.200^{\star}$ & .856 & 9 & 087 \\
\hline hujan_5 & 198 & 9 & $.200^{*}$ & .939 & 9 & .569 \\
\hline hujan_6 & .165 & 9 & $.200^{\star}$ & .925 & 9 & .439 \\
\hline hujan_7 & 261 & 9 & .079 & .866 & 9 & .112 \\
\hline hujan_8 & .136 & 9 & $.200^{\star}$ & .934 & 9 & .522 \\
\hline
\end{tabular}

Hasil uji Kolmogorov-Smirnov untuk tes kenormalan data siklus musim kemarau diperoleh nilai signifikansi untuk semua periode musim kemarau sebesar 0.2.Semua siklus musim kemarau dalam 8 periode mempunyai nilai signifikansi $>0.05$ sehingga residual model regresi yang dilakukan berdistribusi normal.

\begin{tabular}{|c|c|c|c|c|c|c|}
\hline & \multicolumn{3}{|c|}{ Kolmogorov-Smirnov ${ }^{a}$} & \multicolumn{3}{|c|}{ Shapiro-Wilk } \\
\hline & Statistic & df & Sig. & Statistic & df & Sig. \\
\hline kemarau_1 & .179 & 9 & $.200^{*}$ & .952 & 9 & .709 \\
\hline kemarau_2 & .160 & 9 & $.200^{*}$ & 973 & 9 & .918 \\
\hline kemarau_3 & .182 & 9 & $.200^{*}$ & .970 & 9 & .893 \\
\hline kemarau_4 & .158 & 9 & $.200^{*}$ & .982 & 9 & .972 \\
\hline kemarau_5 & .158 & 9 & $.200^{*}$ & .944 & 9 & .621 \\
\hline kemarau_6 & 191 & 9 & $.200^{*}$ & .905 & 9 & .285 \\
\hline kemarau_7 & .218 & 9 & $.200^{*}$ & .888 & 9 & 189 \\
\hline kemarau_8 & .215 & 9 & $.200^{*}$ & .929 & 9 & .472 \\
\hline
\end{tabular}

\subsection{Analisa Trend Curah Hujan}

Analisa kecenderungan curah hujan untuk curah hujan tahunan mulai dari tahun 1915 sampai dengan tahun 2000 untuk stasiun di kota Martapura menunjukan pola kecenderungan kenaikan 4,5898 mm/tahun yang ditunjukan oleh grafik dibawah ini dengan persamaan regresi yang didapat $Y=4.5898 \times-6600.4$ dengan $R^{2}=0.0513$

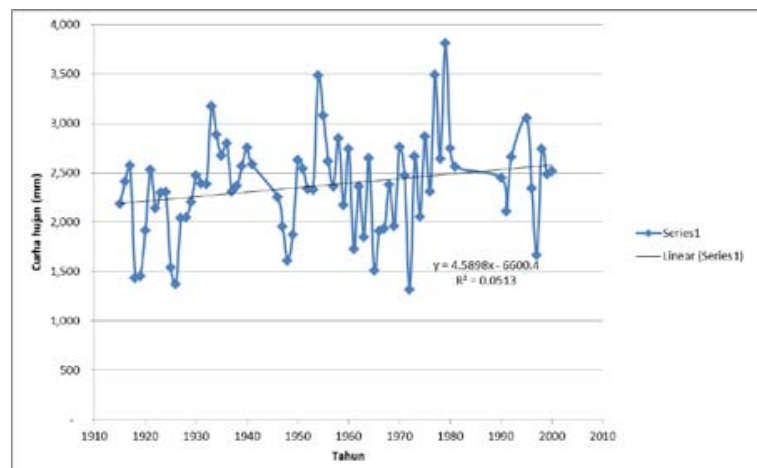

Gambar 8. Curah hujan tahunan stasiun Martapura periode 1915-2000

Dalam grafik diatas berbeda dengan hasil penelitian dari kumagai sebelumnya untuk curah hujan wilayah kalimantan dimana terjadi pola penurunan curah hujan.

\subsection{Analisis Regresi Berganda}

Dari tabel di bawah ini diketahui nilai korelasi untuk musim hujan adalah 0.929 yang berarti menunjukkan adanya hubungan antar periode siklus musim hujan yang saling mempegaruhi dan berkorelasi kuat. $\mathrm{R}$ square = 0.862 yang berarti siklus hujan_1 memberikan pengarauh terhadap siklus hujan lainnya sebesar $86.2 \%$ sedangakan sisanya sebesar $13.8 \%$ dipengaruhi oleh faktor lain.

Model Summary
\begin{tabular}{|l|r|r|r|r|}
\hline Model & R & R Square & $\begin{array}{c}\text { Adjusted } \\
\text { R Square }\end{array}$ & $\begin{array}{c}\text { Std. Error of } \\
\text { the Estimate }\end{array}$ \\
\hline 1 & $.929^{\mathrm{a}}$ & .862 & -.102 & 56.83193 \\
\hline
\end{tabular}
a. Predictors: (Constant), hujan_8, hujan_4, hujan_5,
hujan_6, hujan_3, hujan_2, hujan_7

Pada siklus musim kemarau diketahui nilai korelasinya adalah 1 menunjukkan hubungan antar periode siklus musim kemarau saling mempengaruhi dan berkorelasi kuat. Nilai Adjusted $\mathrm{R}$ square $=0.999$ yang berarti siklus kemarau_1 memberikan pengarauh terhadap siklus kemarau lainnya sebesar $99 \%$ sedangkan sisanya sebesar 
1\% dipengaruhi oleh faktor lain. Hasil selengkapnya dapat dilihat tabel di bawah ini.

\begin{tabular}{|c|c|c|c|c|}
\hline \multicolumn{5}{|c|}{ Model Summary } \\
\hline Model & $\mathrm{R}$ & R Square & $\begin{array}{l}\text { Adjusted } \\
\text { R Square }\end{array}$ & $\begin{array}{l}\text { Std. Error of } \\
\text { the Estimate }\end{array}$ \\
\hline 1 & $1.000^{\mathrm{a}}$ & 1.000 & .999 & .94072 \\
\hline
\end{tabular}

\subsection{Uji F}

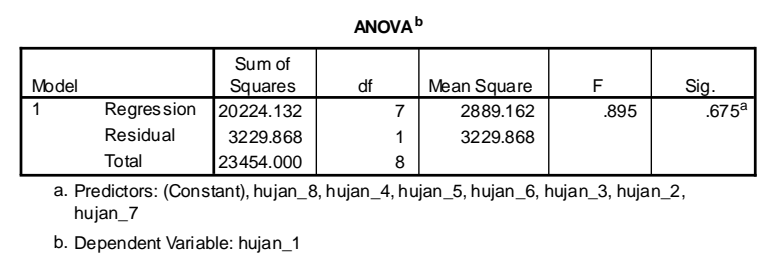

Dari tabel diatas didapat nilai signifikansi $=0.675$ yang berarti > 0.05 dengan demikian model persamaan regresi berdasarkan data penelitian untuk musim hujan tidak signifikan yang berarti pola distribusi curah hujan untuk setiap periode musim hujan sama dibanding periode normalnya (hujan_1).

\begin{tabular}{|c|c|c|c|c|c|c|}
\hline \multicolumn{7}{|c|}{ ANOVA $^{b}$} \\
\hline & & $\begin{array}{l}\text { Sum of } \\
\text { Squares }\end{array}$ & df & Mean Square & $\mathrm{F}$ & \\
\hline & Regression & \begin{tabular}{|l|}
10561.091 \\
\end{tabular} & 7 & 1508.727 & 1704.883 & $.019^{\mathrm{a}}$ \\
\hline & Residual & .885 & 1 & .885 & & \\
\hline & Total & 10561.976 & 8 & & & \\
\hline
\end{tabular}

Dari tabel diatas didapat nilai signifikansi $=0.019$ yang berarti < 0.05 dengan demikian model persamaan regresi berdasarkan data penelitian untuk musim kemarau signifikan yang berarti pola distribusi curah hujan untuk setiap periode musim kemarau tidak sama dibanding periode normalnya (kemarau_1).
Hasil uji t untuk setiap periode musim hujan dibandingkan dengan periode normalnya (hujan_1) dapat dilihat pada tabel dibawah ini:

Coefficients $^{a}$

\begin{tabular}{|c|c|c|c|c|c|c|}
\hline \multirow[b]{2}{*}{ Mode } & & \multicolumn{2}{|c|}{$\begin{array}{l}\text { Unstandardized } \\
\text { Coefficients }\end{array}$} & \multirow{2}{*}{$\begin{array}{c}\text { Standardized } \\
\text { Coefficients } \\
\text { Beta } \\
\end{array}$} & \multirow[b]{2}{*}{$\mathrm{t}$} & \multirow[b]{2}{*}{ Sig. } \\
\hline & & B & Std. Error & & & \\
\hline \multirow[t]{8}{*}{\begin{tabular}{|l|l}
$\mid$ \\
$|c|$
\end{tabular}} & (Constant) & -249.035 & 620.798 & & -.401 & .757 \\
\hline & hujan_2 & -1.142 & .912 & -1.085 & -1.252 & .429 \\
\hline & hujan_3 & 1.662 & 1.312 & 1.207 & 1.267 & .425 \\
\hline & hujan_4 & 1.125 & .808 & 1.371 & 1.392 & .397 \\
\hline & hujan_5 & -4.884 & 2.538 & -3.467 & -1.924 & .305 \\
\hline & hujan_6 & 8.631 & 4.928 & 6.046 & 1.751 & .330 \\
\hline & hujan_7 & -3.332 & 1.975 & -5.587 & -1.687 & .341 \\
\hline & hujan_8 & 1.426 & 1.000 & 1.014 & 1.426 & .389 \\
\hline
\end{tabular}

Dari hasil uji pada tabel diatas diketahui nilai signifikansi untuk semua periode musim hujan $>0.05$ sehingga Ho diterima yang berarti tidak ada perbedaan pola curah hujan pada masing-masing periode musim hujan dari tahun 1914-2000..Pada siklus musim kemarau hasil uji t untuk masingmasing periode dibandingkan dengan periode normalnya dapat dilihat pada tabel di bawah ini.

\begin{tabular}{|c|c|c|c|c|c|c|}
\hline \multicolumn{7}{|c|}{ Coefficients $^{a}$} \\
\hline \multirow[b]{2}{*}{ Mode } & & \multicolumn{2}{|c|}{$\begin{array}{c}\text { Unstandardized } \\
\text { Coefficients }\end{array}$} & \multirow{2}{*}{$\begin{array}{c}\begin{array}{c}\text { Standardized } \\
\text { Coefficients }\end{array} \\
\text { Beta } \\
\end{array}$} & \multirow[b]{2}{*}{$t$} & \multirow[b]{2}{*}{ Sig. } \\
\hline & & $B$ & Std. Error & & & \\
\hline 1 & (Constant) & 62.634 & 5.682 & & 11.023 & .058 \\
\hline & kemarau_2 & 1.072 & .030 & .774 & 35.458 & .018 \\
\hline & kemarau_3 & 1.479 & .022 & 1.481 & 67.645 & .009 \\
\hline & kemarau_4 & -.067 & .012 & -.066 & -5.593 & .113 \\
\hline & kemarau_5 & -.771 & .015 & -.938 & -51.616 & .012 \\
\hline & kemarau_6 & -237 & .013 & -368 & -17.627 & .036 \\
\hline & kemarau_7 & -.339 & .023 & -196 & -14.564 & .044 \\
\hline & kemarau_8 & -.798 & .012 & -1.036 & -66.211 & .010 \\
\hline
\end{tabular}

Nilai signifikansi untuk tiap periode musim kemarau < 0.05 sehingga Ho ditolak yang berarti telah terjadi perbedaan pola curah hujan untuk musim kemarau dibandingkan periode normalnya yaitu kemarau_1, kecuali untuk periode 4 dimana nilai signifikansi $>0.05$ yang berarti pada periode tidak terdapat perbedaan pola curah hujan dibandingkan periode normalnya. Perubahan pola siklus musim hujan (a) dan musim kemarau (b) untuk masing-masing periode dibandingkan dibandingkan siklus normalnya terlihat pada grafik dibawah ini.

\section{$4.5 \quad$ Uji $t$}

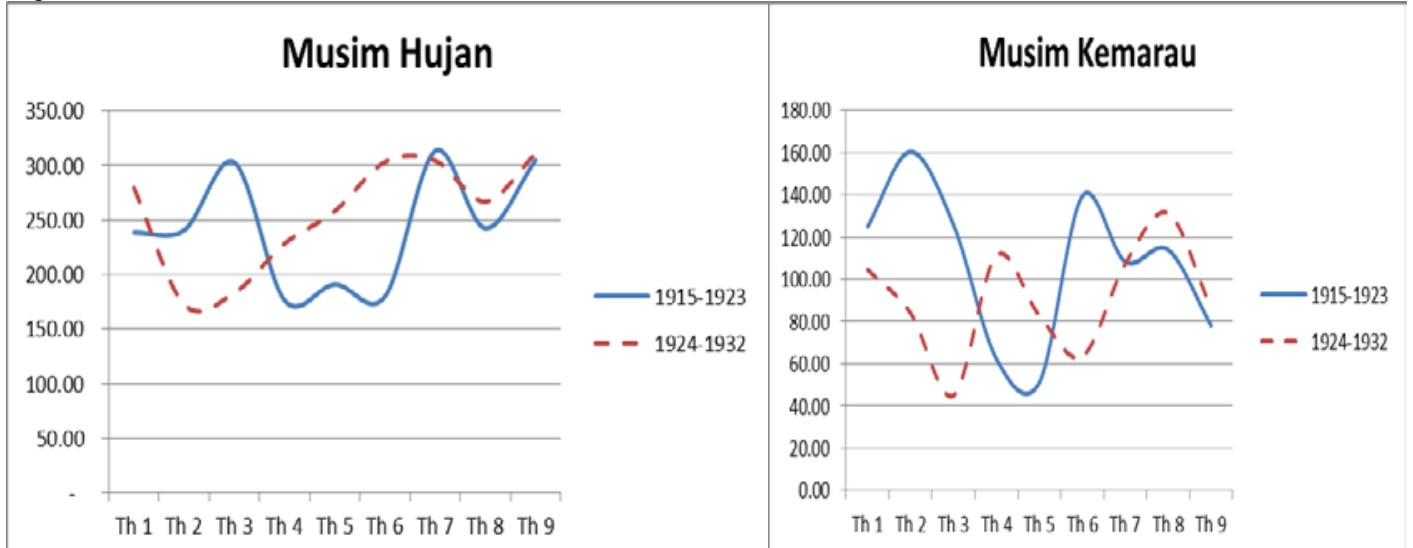

Gambar 9.Pola siklus musim hujan dan musim kemarau tahun 1915-1923 dan 1923-1932. 


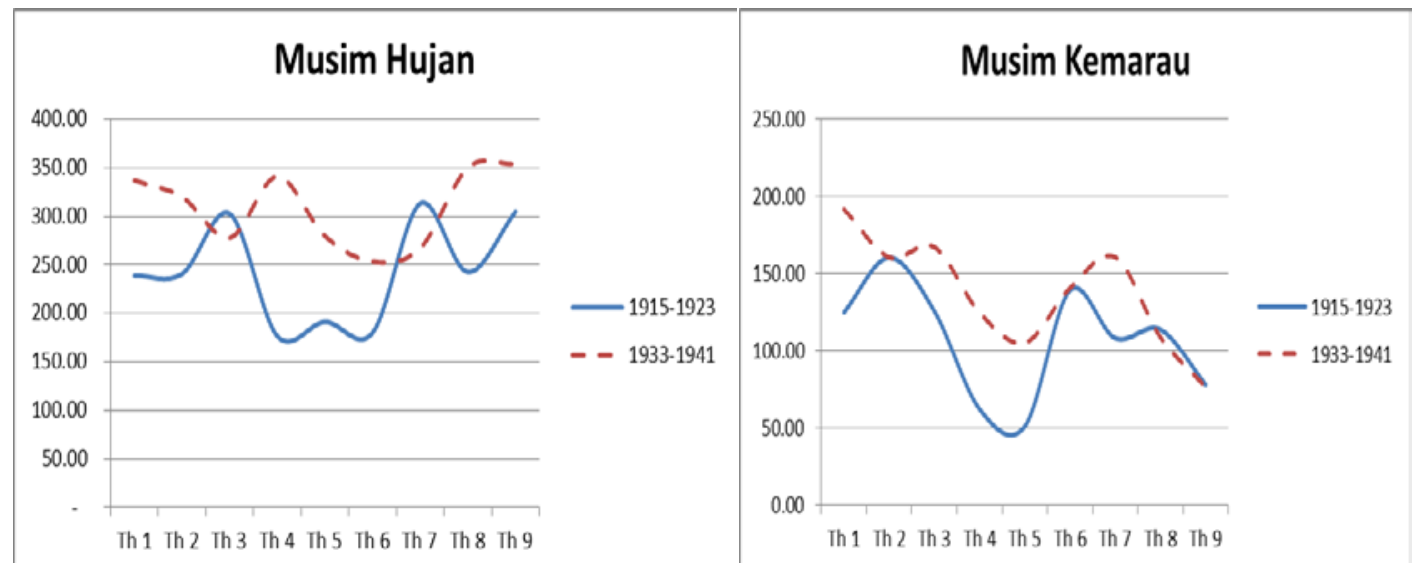

Gambar 10. Pola siklus musim hujan dan musim kemarau tahun 1915-1923 dan 1933-1941

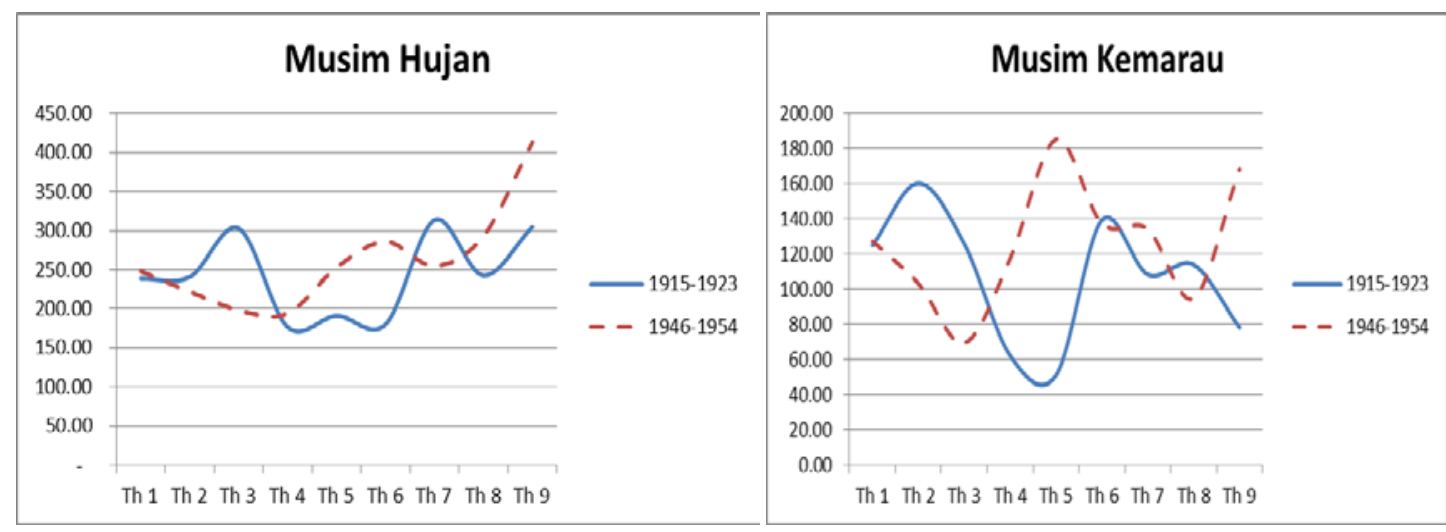

Gambar 11. Pola siklus musim hujan dan musim kemarau tahun 1915-1923 dan 1946-1954

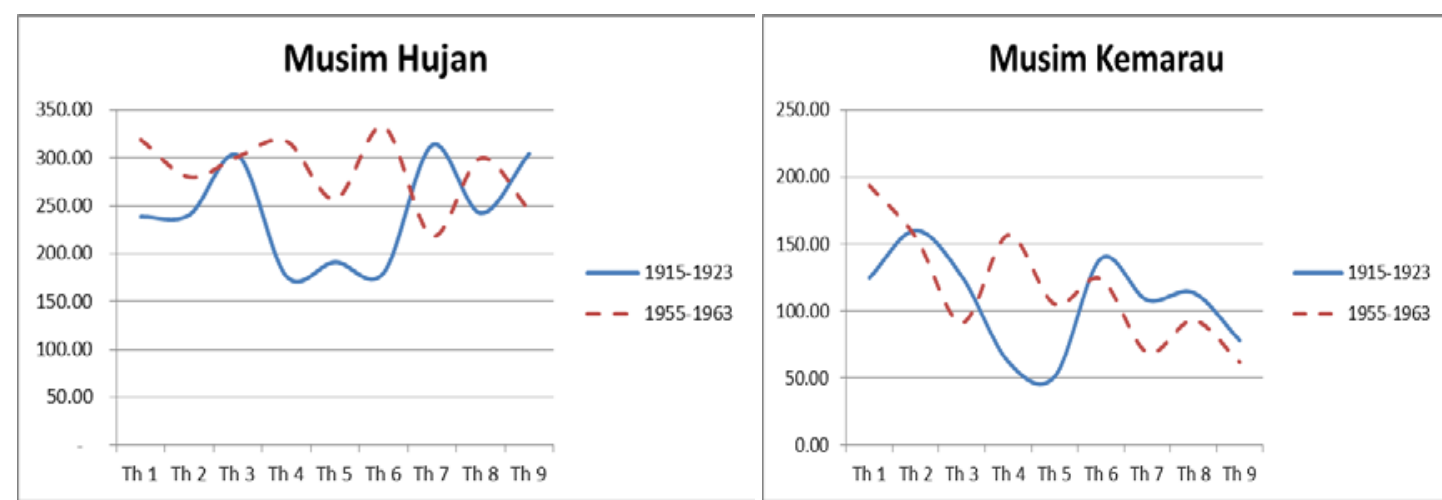

Gambar 12. Pola siklus musim hujan dan musim kemarau tahun 1915-1923 dan 1955-1963

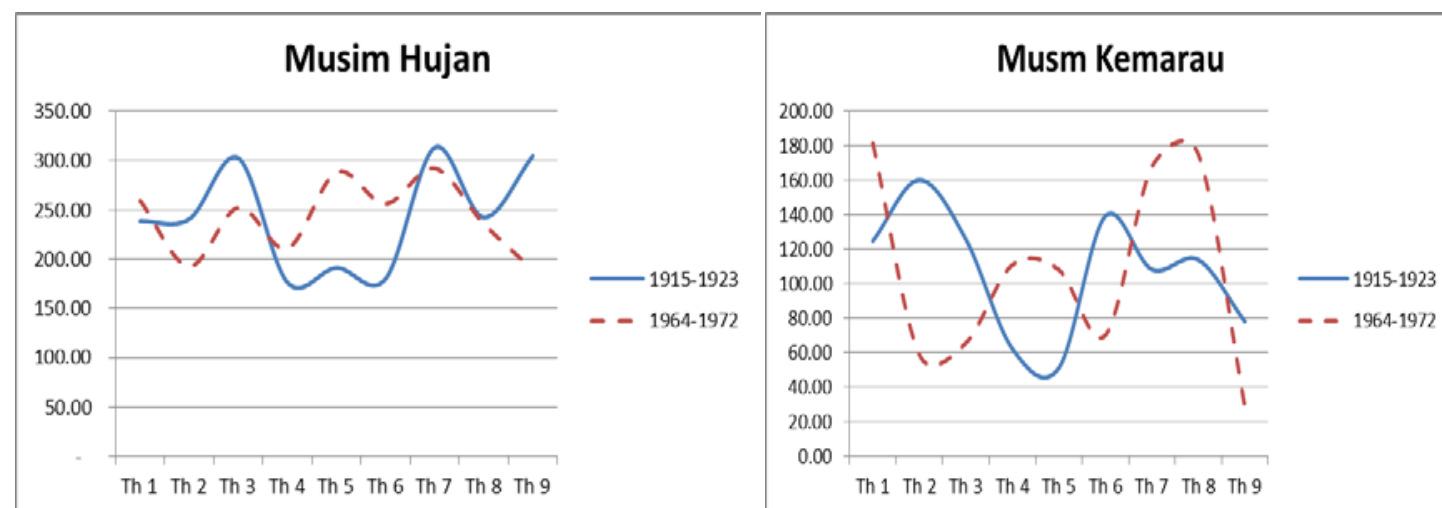

Gambar 13. Pola siklus musim hujan dan musim kemarau tahun 1915-1923 dan 1964-1972 


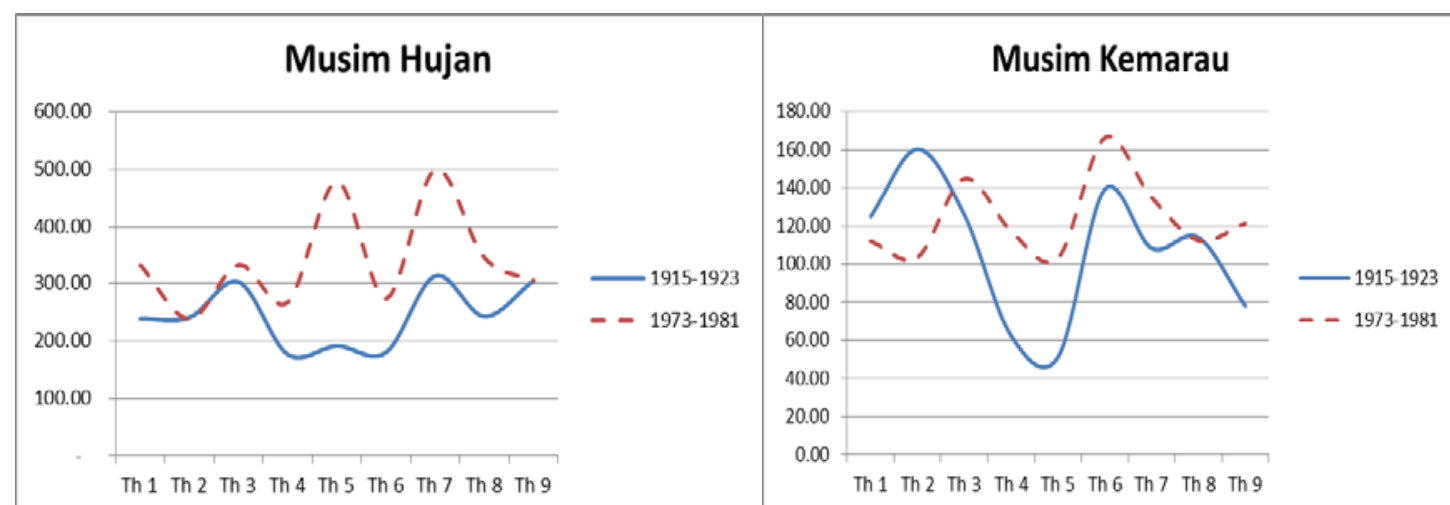

Gambar 14. Pola siklus musim hujan dan musim kemarau tahun 1915-1923 dan 1973-1981

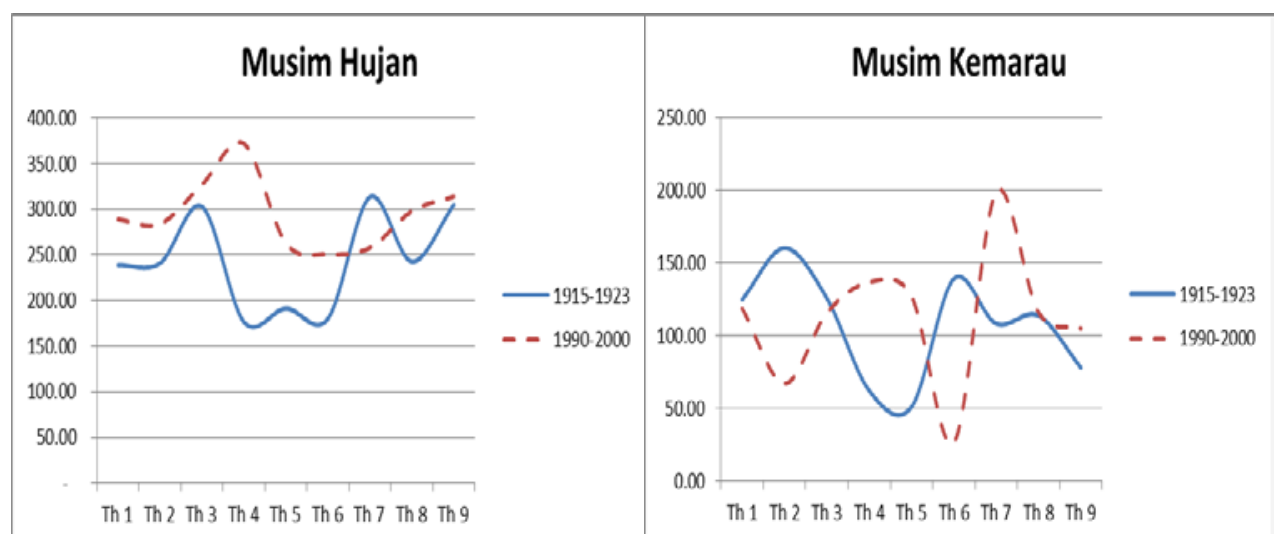

Gambar 15. Pola siklus musim hujan dan musim kemarau tahun 1915-1923 dan 1990-2000

Dari beberapa gambar pola curah hujan pada musim hujan dan musim kemarau diatas dapat dilihat untuk pola musim hujan setiap periode hampir sama dengan periode normalnya sedangkan pada musim kemarau dari setiap periode lebih berbeda dibandingkan periode normalnya.

\section{KESIMPULAN}

Dari hasil analisis data curah hujan untuk stasiun hujan Martapura dari tahun 1915-2000 yang dibagi ke dalam 8 periode dapat disimpulkan sebagai berikut :

- Dari hasil pemodelan analisis regresi curah hujan di stasiun Martapura dari tahun 19152000 menunjukan pola kecenderungan kenaikan 4,5898 mm/tahun..

- Pola curah hujan pada musim hujan untuk setiap periode dibandingkan dengan periode normalnya tidak terdapat perbedaan yang signifikan, sebaliknya pada musim kemarau terjadi perbedaan pola curah hujan dari setiap periode dibandingkan periode normalnya kecuali untuk periode 4 (1946-1954).

- Perubahan pola curah hujan dari tahun 19152000 terjadi pada musim kemarau.

\section{DAFTAR PUSTAKA}

Gaveau, David, 2015. Forest Loss, Degradation and Fire in The Equatorial Forest of Southeast Asia, Seminar IImiah BMKG

Greenpeace SEA, Hutan Tropis Indonesia dan Krisis Iklim, Jakarta: greenpeace.org

Handajani, Novie, 2005. Analisa Distribusi Curah Hujan dengan Kalang Ulang Tertentu, UPN, Jawa Timur.

Hanifah, A., dan Endarwin, 2010. Analisa Intenstitas Curah Hujan Wilayah Bandung Pada Awal 2010. Jurnal Meteorologi dan Geofisika Vol. 12 No.2

Kismiantini, 2010. Handout Analisis Regresi, Jurusan Pendidikan Matematika, Universitas Negeri Yogyakarta

Kumagai, T., Hironari Kanamori, Tetsuzo Yasunari, 2013. Deforestation - induced Reduction in Rainfall, Hydrol. Process. 27, 3811-3814 (2013)

Setiawan, Ogi, 2012. Analisis Variabilitas Curah Hujan dan Suhu di Bali, NTB, Balai Penelitian Teknologi Hasil Hutan Kayu

Soemanto, C.D., 1995. Hidrologi Teknik, Erlangga 